\title{
PROMOTING THE INCREASE OF MATHEMATICAL REPRESENTATIVE SKILL IN VOCATIONAL STUDENTS THROUGH BLENDED PROBLEM-BASED LEARNING
}

\author{
Sri Rahayu Setiyorini ${ }^{1}$ and Azalina Nurul Fajariah ${ }^{2}$ \\ ${ }^{1,2}$ Mathematics Education Departement (Master Program), IKIP Siliwangi, Cimahi \\ ${ }^{1}$ sr.setiyorini@gmail.com, ${ }^{2}$ azalina93nurul@gmail.com
}

Received: Jul 11 ${ }^{\text {th }}$, 2019; Accepted: Jul 18 ${ }^{\text {th }}, 2019$

\begin{abstract}
This research is aimed to evaluate BL-PBL effect to mathematical representation skill escalation in vocational high school. Method used in this research were pre-test and post-test control group design, which performed to two randomly-chosen classes over vocational schools in Kabupaten Bandung Barat, West Java, Indonesia. Samples were divided into two groups: experimental (BL-PBL method) and control (lecture method). Initial skill was determined by pre-test while learning outcome was determined using post-test. Data was analysed by t-test and two-way ANOVA with .05 significance level using IBM SPSS. Result showed that the initial skill of two groups was similar. After treatment, $\mathrm{N}$-gain data uncovered a significant increase of representative skill in experimental group. While, twoway ANOVA test showed no interaction between learning model used and student grouping based on initial skill to representation skill. Finally, BL-PBL was proven to increase mathematical representation skill in vocational students and, hence, is suggested to be implemented in vocational high school.
\end{abstract}

Keywords: Blended Learning, Problem-Based Learning, Representative Skill

\begin{abstract}
Abstrak
Penelitian ini bertujuan untuk menentukan pengaruh penggunaan metode blended learning (BL) berbasis problem-based learning (PBL) terhadap peningkatan kemampuan representasi matematis siswa Sekolah Menengah Kejuruan (SMK). Metode yang digunakan adalah pretes dan postes kelompok kontrol pada dua kelas yang dipilih secara acak dari seluruh SMK di Kabupaten Bandung Barat, Jawa Barat. Sampel kemudian dibagi menjadi kelompok perlakuan: eksperimen (pembelajaran BL berbasis PBL) serta kontrol (pembelajaran konvensional). Kemampuan awal ditentukan dengan pre-test sementara hasil pembelajaran ditentukan lewat post-test. Data dianalisis dengan uji t dan uji ANOVA dua jalur pada taraf signifikansi 0,05 menggunakan IBM SPSS. Hasil menunjukkan kemampuan awal kedua kelompok. Setelah perlakuan, data N-gain mengungkap peningkatan signifikan kemampuan representasi matematis pada kelompok eksperimen. Hasil uji ANOVA dua jalur menunjukkan tidak ada interaksi kemampuan awal dan model PBL dengan kemampuan representasi matematis. Dapat disimpulkan bahwa penggunaan metode BL berbasis PBL mampu meningkatkan kemampuan representasi matematis siswa SMK. Sehingga, metode BL berbasis PBL dapat diterapkan untuk meningkatkan kemampuan representasi matematis siswa SMK .
\end{abstract}

Kata Kunci: Blended Learning, Problem-Based Learning, Kemampuan Representasi

How to Cite: Setiyorini, Sri Rahayu. \& Fajariah, Azalina Nurul. (2019). Promoting the Increase of Mathematical Representative Skill in Vocational Students through Blended Problem-Based Learning. JIML, 2 (2), 65-73. 
66 Setiyorini, SR. \& Fajariah, AN. Promoting the Increase of Mathematical Representative Skill in Vocational Students through Blended Problem-Based Learning

\section{INTRODUCTION}

Mathematical representation skill is the ability of interpreting someone's thought in the form of words, pictures, tables, graphs, concrete things, mathematical symbols, etc. to be used as a tool in problem solving (Syafri, 2017; Tandililing \& Hartoyo, 2016). Therefore, mathematical representation skill is important in promoting logical, systematical, critical, and creative thinking ability; as stated in the purpose of studying mathematics.

In vocational high school, especially in technology and engineering expertise group, subjects such as technical drawing and energy conversion are highly correlated with mathematics. These subjects need mathematical representation skill to understand (Arifin \& Ristadi, 2017; Warso, 2017). However, data shows that mathematical representation skill of vocational high school students is low (Hasibuan, 2017; Indrati, 2017; Kusumawati, 2017; Maulydia, 2017; Tyas, 2016). This correlates with the inability of vocational students to solve mathematical problems (Armanto, Armanto, \& Harahap, 2014; Asmara, 2016; Ramandani, Mahardika, \& Supriadi, 2017; Syafri, 2017). Adiastuty (2015) supported the findings by stating that the level of pleasure given by studying mathematics in vocational students is also low. Those problems are caused by many factors, one of them is due to the use of conventional methods of teaching (lecturing) by mathematics teachers which restricts mathematical representative skill optimal growth and development (Chen, Lee, \& Hsu, 2015).

Arifin \& Ristadi (2017) showed that vocational high school graduates still contributed the most to the amount of jobless people in Indonesia. The low level of knowledge and skill owned by vocational high school graduates was then concluded as the main reason why many of them could not be absorbed by the industry. It was surveyed that the unskilled and unknowledge vocational high school graduates faced difficulties of internalizing and understanding a problem. Therefore, graduates were observed to be inflexible and uncreative in solving daily problems, especially those which were correlated with mathematics. This makes vocational high school graduates less competitive compared to other candidates in company recruitment or building their own business.

Therefore, it is clear that a planning in mathematics teaching which contains developable approaches and models for vocational students is needed. One of the approaches developed is blended learning, a combination of face to face (offline) and online learning (Purnomo, Ratnawati, \& Aristin, 2016; Surahman \& Surjono, 2017). This approach fills the gap of offline learning developed in Kurikulum 13 related to scientific approach, yet also prepare students for the upcoming industry era where everything is done through online instructions.

It is widely known that problem-based learning is effective to develop mathematical skill. Using problems as its key feature, this learning method focuses in cognitive aspect to find solutions, starting with serving contextual problem to understand concept (Mulyana \& Sumarmo, 2015). Special characteristic of problem-based learning is that students are active in building detail knowledge through researching, data collecting, and problem solving by building cause and effect relationship to solve a problem (Asmara, 2016; Mulyana \& Sumarmo, 2015; Tandiling, 2015). Furthermore, this student-centered model also explores all mathematics skills (Mulyana \& Sumarmo, 2015). Problem-based learning has several excellences, such as: 1) preparing students to face daily problems, 2) teaching students to dig new knowledge independently, 3) helping students in developing mathematical representation skill as well as other mathematical skills (Aziz, Ahyan, \& Fauzi, 2016; Tera, 2016). 
Learning method used in this study combines offline problem-based learning and online learning. Two days before offline learning in class is held, teacher uploads materials and tasks in Whatsapp media to dig into students' basic skill and to promote them learn new things. Then, offline learning is held in classes using problem-based learning.

Therefore, it is concluded that blended problem-based learning is aimed to: 1) measure the increase of mathematical representation skill in vocational students taught using blended problem-based learning compared to vocational students taught using conventional method, and 2) know the interaction of blended problem-based learning with student grouping based on initial mathematical skill compared to the increase of mathematical representation skill. Looking at the benefits and how promising it is, blended problem-based mathematics learning in technology and engineering vocational high school is expected to solve learning problems described before.

\section{METHOD}

This research was a quantitative research with pre-test and post-test control group design. Therefore, instruments used were arranged in the form of pre-test and post-test. Population of the research consisted of all the first-year students of vocational high schools in Kabupaten Bandung Barat. Samples were randomly selected and two classes in SMK Karya Pembangunan Bandung Barat were chosen. A class of X TP 3 was determined as the experiment group which received blended problem-based learning while class of X TP 1 was determined as control group which received the usual scientific approach learning model. Before treatment, the groups were given a pre-test to know their initial mathematical skill. The initial skill was then compared between experiment and control group. Pre-test was also used to group students into high, middle, and low achiever.

Material delivered in the study was arithmetical sequence and series. To analyze the data, $t$ test and two-way ANOVA with significance value of .05 were used. The test results were collected and analyzed using IBM SPSS ver. 19. Statistical features, frequency and percentage were used to describe statistical features. The collected data was presented in the form of table to make comparison between similarities and differences between groups easier. Achievement of representation skill was determined from post-test scores and analyzed by independent sample t-test. To see if the learning outcome, which was representation skill, was correlated to learning method and initial mathematical skill, two-way ANOVA was used.

\section{RESULTS AND DISCUSSION}

\section{Results}

\section{Initial Mathematical Skill Assessment}

By using post-test scores according to following criteria (Table 1), number of students and their achieving level in each group can be determined as follows.

Table 1. Grouping of Students' Initial Skill Based on Pre-Test Scores

\begin{tabular}{cccc}
\hline Criteria & Label & $\begin{array}{c}\text { Control } \\
\text { (number of } \\
\text { students) }\end{array}$ & $\begin{array}{c}\text { Experimental } \\
\text { (number of } \\
\text { students) }\end{array}$ \\
\hline $55<N \leq 100$ & High & $6(24 \%)$ & $7(28 \%)$ \\
$45<N \leq 55$ & Middle & $13(52 \%)$ & $12(48 \%)$ \\
$N \leq 45$ & Low & $6(24 \%)$ & $6(24 \%)$ \\
\hline
\end{tabular}


68 Setiyorini, SR. \& Fajariah, AN. Promoting the Increase of Mathematical Representative Skill in Vocational Students through Blended Problem-Based Learning

It was very important to make sure that the initial mathematical skill between students in treatment groups were similar to eliminate bias. Therefore independent samples $t$-test was performed following normality and homogeneity tests to pre-test scores gathered from both groups. The analysis is shown in Table 2.

Table 2. Measurement of Initial Skills Difference between Treatments.

\begin{tabular}{cccccc}
\hline & F & Sig. & T & Df & Sig. (2-tailed) \\
\hline Pre-test & .019 & .890 & .028 & 48 & .978 \\
\hline
\end{tabular}

Independent samples $t$-test performed on pre-test scores of each group showed that $t_{\text {count }}=.028<t_{\text {table }}=.680$ and $p$ value $=.489>.05$. The result indicated that there was no significant difference of initial skill between both groups. It was concluded that both experimental and control group had similar initial mathematical skill before treatment proceeded.

\section{Representation Skill Achievement}

Following treatment, post-test was held and the scores were gathered. To assess which treatment gave better learning outcome, $t$-test was performed to post-test scores following normality and homogeneity tests. Table 3 shows that $t_{\text {count }}=5.480>t_{\text {table }}=.680$ and $p$ value $<.05$, indicating there was significant difference of learning outcome between groups. Therefore, conclusion was drawn that blended problem-based learning was more effective compared to conventional approach.

Table $3 t$-Test Analysis to Determine Differences in Learning Outcome.

\begin{tabular}{cccccc}
\hline \multirow{2}{*}{ Post-test } & F & Sig. & T & df & $\begin{array}{c}\text { Sig. (2- } \\
\text { tailed) }\end{array}$ \\
\cline { 2 - 6 } & 2.363 & .163 & -5.580 & 48 & .000 \\
\hline
\end{tabular}

Analysis of pre- and post-test were shown in Table 4. In the analysis of pre-test scores, it was observed that $t_{\text {count }}<t_{\text {table }}$ and $p>.05$ in high and middle achieving students. While, $t_{\text {count }}>t_{\text {table }}$ where $t_{\text {count }}$ was negative and $p>.05$ was observed in low achieving students.

Table 4. $t$ And $p$ Value of Pre-Test and Post-Test Scores Analysis According to Initial Mathematical Skill of Students.

\begin{tabular}{llllllll}
\hline Skill & Group & $\mathbf{N}$ & Mean & SD & MD & T & $\boldsymbol{p}$ value \\
\hline Pretest & & & & & & & \\
\hline \multirow{2}{*}{ High } & Experimental & 7 & 57.86 & 2.037 & .143 & .133 & .448 \\
\cline { 2 - 8 } & Control & 6 & 58.00 & 1.789 & & & .049 \\
\multirow{2}{*}{ Middle } & Experimental & 12 & 48.92 & 4.122 & .083 & .481 \\
\cline { 2 - 8 } & Control & 13 & 49.00 & 4.282 & & & \\
\hline \multirow{2}{*}{ Low } & Experimental & 6 & 36.00 & 1.673 & -1.833 & -1.534 & .078 \\
\cline { 2 - 8 } & Control & 6 & 37.83 & 2.401 & & & \\
\hline
\end{tabular}




\begin{tabular}{|c|c|c|c|c|c|c|c|}
\hline Posttest & & & & & & & \\
\hline \multirow{2}{*}{ High } & Experimental & 7 & 86.57 & 2.070 & 9.238 & 7.561 & .000 \\
\hline & Control & 6 & 77.33 & 2.338 & & & \\
\hline \multirow{2}{*}{ Middle } & Experimental & 12 & 76.92 & 3.059 & 7.455 & 4.617 & .000 \\
\hline & Control & 13 & 69.46 & 4.754 & & & \\
\hline \multirow{2}{*}{ Low } & Experimental & 6 & 68.67 & 4.367 & 8.667 & 3.250 & .005 \\
\hline & Control & 6 & 60.00 & 4.858 & & & \\
\hline
\end{tabular}

As previously describes, Table 4 shows that there was no significant difference in initial mathematical skill between groups. While, in analysis of post-test scores, initial mathematical skill of students categorized into high, middle, and low achieving was observed to be $t_{\text {count }}>t_{\text {table }}$, where $p>.05$. The result showed that there was significant difference between experimental and control group.

\section{The Increasing of Mathematical Representation Skill}

To see if there was increasement in mathematical representation skill, N-Gain data as used. Before performing independent samples test to N-Gain scores, normality and homogenity tests were performed. Table 5. showed that $t_{\text {count }}=8.827>t_{\text {table }}=.680$ and $p$ value $<.05$, indicating that there was significant increase of learning outcome between experimental group, which received blended-problem based learning, and control group, which received ordinary lecture method.

Table 5. Independent Samples t-Test to Learning Outcome Result.

\begin{tabular}{llllll}
\hline & F & Sig. & t & df & Sig. (2-tailed) \\
\hline N Gain & .839 & .364 & -8.827 & 48 & .000 \\
\hline
\end{tabular}

Interaction between Initial Skill and Blended Problem-Based Learning and Mathematical Representation Skill

After the N-gain data of each experimental and control group was assessed and known to be normally distributed with homogeny data variance (Table 6.). Therefore, to understand the whole effect of data group, two-way ANOVA was performed. Significance of corrected model showed .000, meaning the model was valid. Significant intercept was detected as significance of the intercept was calculated to be $.000 . p$ value was $<.05$ for learning variable, indicating that there was significant effect of blended problem-based learning to mathematical representation skill. Whereas, $p$ value $<.05$ for initial skill variable indicated that there was significant difference of learning outcome in students with high, middle, and low achievement level treated with blended problem-based learning. However, for the interaction between model factor and initial mathematical skill, $p$ value $>.05$ indicating no significant correlation. Error model value was better because it got smaller. While, R squared value was .991, close to 1 , indicating a strong correlation. 
70 Setiyorini, SR. \& Fajariah, AN. Promoting the Increase of Mathematical Representative Skill in Vocational Students through Blended Problem-Based Learning

Table 6. Tests of Between-Subjects Effects

\begin{tabular}{lccccc}
\hline \multicolumn{1}{c}{ Source } & $\begin{array}{c}\text { Type III Sum of } \\
\text { Squares }\end{array}$ & Df & Mean Square & F & Sig. \\
\hline Corrected Model & $.907^{\mathrm{a}}$ & 5 & .181 & 90.512 & .000 \\
\hline Intercept & 9.460 & 1 & 9.460 & 4718.411 & .000 \\
\hline Learning & .562 & 1 & .562 & 280.447 & .000 \\
\hline Initial Skill & .283 & 2 & .142 & 70.587 & .000 \\
\hline Learning * Initial Skill & .008 & 2 & .004 & 2.010 & .146 \\
\hline Error & .088 & 44 & .002 & & \\
\hline Total & 11.456 & 50 & & & \\
\hline Corrected Total & .996 & 49 & & & \\
\hline
\end{tabular}

a. R Squared $=.911$ (Adjusted R Squared $=.901)$

\section{Discussion}

Data analysis showed that the use of blended problem-based learning could escalate mathematical representative skill of vocational students in arithmetical sequence and series material. In line with the result, it was also observed that students from treatment group had higher learning interest compared to students from control group. Treated students seemed to be more ready in receiving information, more understanding the concepts given, and more explorative when solving problems in class. However, control students were observed to be passive and mono-directed.

According to Olivier \& Trigwell (Simarmata, Djohar, Purba, \& Juanda, 2018), the observed phenomenon are related to student-subject engagement triggered by blended problem-based learning. The word blend in blended learning, more than just defining the combination of online and offline learning, also means knowledge blending. Exploration of new knowledge from online resources, outside from the frame of knowledge given by teacher at school, is useful to make students see the world openly in a wider point of view.

Blended learning is also famous for its flexibility of giving students opportunity to arrange their learning independently according to their self-ability. During independent online learning, student can use their time for no limit whenever they want, in contrast to the timemeasured learning in class. Therefore, students can adjust the time needed for them to understand information without slowing down or fastening up others (Lin, Tseng, \& Chiang, 2017; Stockwell, Stockwell, Cennamo, \& Jiang, 2015). This method boosts the understanding of students in all group of achievement, as showed in the learning outcome analysis in each group of achievement.

Students are also given opportunity to choose how they would like to learn about new knowledge depending to their learning styles. Material flexibility and availability given in blended learning, such as video and multimedia animation, can accommodate various learning styles (Lin et al., 2017; Rahman \& Ahmar, 2016) while increasing auditory, observation, language, and cognitive aspect of the students (Stockwell et al., 2015). This flexibility 
increases student-subject engagement and makes learning activity fun yet enjoyable. Therefore, as showed by student behavior observation in class, learning activity and efficiency increases (Aldalalah \& Gasaymeh, 2014).

Post-test instruments were designed to evaluate students' representative skill after experiment was finished. According to post-test analysis result, it was seen that scores gained by both treated and control students were correlated with their performance in class. In line with Widakdo (2017), students receiving blended problem-based learning could represent daily life problems to mathematical sentences better. Thus, they could solve the problems easily by using mathematical tools and approach. Students' creativity was also proved by various approaches used to solve a given problem, according to how each student understood the problem. In contrast, student receiving conventional teaching method faced difficulties to represent a daily problem into mathematical sentences. Their answers were also similar, showing their creativity and understanding were not explored well.

According to Oliver (2005); Stockwell et al. (2015), students receiving blended problembased learning have enough fundamental and basic knowledge needed to solve problems given during offline learning in class. The fundamental knowledge is seemed to gather during online learning, supported by learning resources available in the internet (Lin et al., 2017; Simarmata et al., 2018). Then, the gathered fundamental knowledge is sharpened by problembased learning during offline learning. As learning materials were given early before offline meetings started, teacher could maximize their time to focus on building and training representative skill. Teachers can also give coaching session to students facing difficulties. In contrast, during conventional learning, teachers face difficulties managing their time to deliver information and to give exercise. As the result, not all needed information are delivered and less exercises are conducted, making the conventional-styled students cannot build their own knowledge and representative skill (Stockwell et al., 2015). Therefore, the students' thinking pattern and approaches used to solve problems are similar and seems to be not well-developed.

\section{CONCLUSION}

According to data analysis and discussion, it was concluded that the increasing of mathematical representation skill of students receiving blended problem-based learning was better than students receiving conventional learning. Therefore, blended problem-based learning is effective to increase and to achieve mathematical representative skill in vocational high school.

\section{ACKNOWLEDGMENTS}

The author would like to thank SMK Karya Pembangunan Padalarang for allowing this study to be carried out there.

\section{REFERENCES}

Adiastuty, N. (2015). Tahapan pembelajaran matematika SMK yang mengarah pada pemecahan masalah (polya). Euclid, 2(2).

Aldalalah, O. A., \& Gasaymeh, A.-M. M. (2014). Perceptions of Blended Learning Competencies and Obstacles among Educational Technology Students in Light of Different Anxiety Levels and Locus of Control. Contemporary Educational Technology, 
72 Setiyorini, SR. \& Fajariah, AN. Promoting the Increase of Mathematical

Representative Skill in Vocational Students through Blended Problem-Based Learning

$5(3), 218-238$.

Arifin, A. N., \& Ristadi, F. A. (2017). Relevansi Kompetensi Teknik Gambar Manufaktur di SMK Terhadap Kebutuhan Industri. JURNAL DINAMIKA VOKASIONAL TEKNIK MESIN, 2(2), 105-110.

Armanto, S., Armanto, D., \& Harahap, M. B. (2014). Perbedaan Penerapan Model Pembelajaran Kooperatif Tipe Jigsaw dan STAD Ditinjau dari Kemampuan Penalaran dan Komunikasi Matematis Siswa SMA. Jurnal Didaktik Matematika, 1(1).

Asmara, A. S. (2016). Peningkatan kemampuan pemecahan masalah dan disposisi matematis siswa SMK dengan pembelajaran berbasis masalah berbantuan multimedia interactive. Jurnal Sekolah Dasar, 1(1).

Aziz, A., Ahyan, S., \& Fauzi, L. M. (2016). Implementasi model Problem Based Learning (PBL) dalam meningkatkan kemampuan berpikir kritis mahasiswa melalui Lesson Study. Jurnal Elemen, 2(1), 83-91.

Chen, M.-J., Lee, C.-Y., \& Hsu, W.-C. (2015). Influence of mathematical representation and mathematics self-efficacy on the learning effectiveness of fifth graders in pattern reasoning. International Journal of Learning, Teaching and Educational Research, 13(1).

Hasibuan, S. H. (2017). Pengaruh model pembelajaran berbasis masalah terhadap kemampuan berpikir kritis dan representasi matematis siswa kelas XI rekayasa perangkat lunak SMKN Binaan Provinsi Sumatera Utara TA 2016/2017 (UNIMED). Retrieved from http://digilib.unimed.ac.id/25034/

Indrati, D. R. (2017). Peningkatan kemampuan representasi matematis dan self-efficacy siswa dengan pendekatan pembelajaran metakognisi di SMK Swasta PAB 2 Helvetia (UNIMED). Retrieved from http://digilib.unimed.ac.id/24503/

Kusumawati, A. D. E. F. (2017). Pengaruh pembelajaran matematika melalui strategi react dengan pendekatan open-ended terhadap kemampuan representasi matematis dan kecemasan matematika siswa SMK di Kota Bandung (FKIP Unpas). Retrieved from http://repository.unpas.ac.id/30400/

Lin, Y.-W., Tseng, C.-L., \& Chiang, P.-J. (2017). The Effect of Blended Learning in Mathematics Course. Eurasia Journal of Mathematics, Science \& Technology Education, 13(3).

Maulydia, S. S. (2017). Hubungan antara kemampuan representasi matematis dengan kepercayaan diri, kemandirian belajar, motivasi belajar, disposisi matematis dan gender siswa SMK (UNIMED). Retrieved from http://digilib.unimed.ac.id/26798/

Mulyana, A., \& Sumarmo, U. (2015). Meningkatkan kemampuan penalaran matematik dan kemandirian belajar siswa SMP melalui pembelajaran berbasis masalah. Didaktik, 9(1), $40-51$.

Oliver, R. (2005). Using a blended learning approach to support problem-based learning with first year students in large undergraduate classes.

Purnomo, A., Ratnawati, N., \& Aristin, N. F. (2016). Pengembangan Pembelajaran Blended Learning Pada Generasi Z. Jurnal Teori Dan Praksis Pembelajaran IPS, 1(1), 70-76.

Rahman, A., \& Ahmar, A. (2016). Exploration of mathematics problem solving process based on the thinking level of students in junior high school.

Ramandani, N. I., Mahardika, I. K., \& Supriadi, B. (2017). Peningkatkan kemampuan representasi verbal dan matematik siswa kelas X GB 1 di SMKN 2 Jember melalui model PBI disertai LKS berbasis multirepresentasi. FKIP E-Proceeding, 2(1), 5.

Simarmata, J., Djohar, A., Purba, J., \& Juanda, E. A. (2018). Design of a Blended Learning Environment Based on Merrill's Principles. Journal of Physics: Conference Series, 954(1), 12005. IOP Publishing.

Stockwell, B. R., Stockwell, M. S., Cennamo, M., \& Jiang, E. (2015). Blended learning 
improves science education. Cell, 162(5), 933-936.

Surahman, E., \& Surjono, H. D. (2017). Pengembangan adaptive mobile learning pada mata pelajaran biologi SMA sebagai upaya mendukung proses blended learning. Jurnal Inovasi Teknologi Pendidikan, 4(1), 26-37.

Syafri, F. S. (2017). Kemampuan Representasi Matematis dan Kemampuan Pembuktian Matematika. JURNAL E-DuMath, 3(1).

Tandililing, E., \& Hartoyo, A. (2016). Pembelajaran NHT berstruktur antisipasi didaktis untuk meningkatkan kemampuan representasi matematis dan penyelesaian masalah matematika. Jurnal Pendidikan Dan Pembelajaran, 6(3).

Tandiling, E. (2015). Effectivity of Problem Based Learning (PBL) in improving students' mathematical representation. Proceeding of International Conference On Research, Implementation, and Education of Mathematics and Sciences, 151.

Tera, S. (2016). Penerapan model problem-based learning dengan menggunakan teknik quantum learning dalam meningkatkan keaktifan belajar peserta didik pada mata pelajaran pendidikan kewarganegaraan.(penelitian tindakan kelas pada materi kasus pelanggaran HAM pada kelas XI (FKIP UNPAS). Retrieved from http://repository.unpas.ac.id/13040/

Tyas, W. H. (2016). Representasi Matematis Siswa dalam Menyelesaikan Masalah Matematika pada Materi Aritmatika Sosial dan Perbandingan Ditinjau dari Gaya Kognitif Siswa Kelas VII SMP Negeri 15 Surakarta Tahun Ajaran 2014/2015 (UNS (Sebelas Maret University)). Retrieved from http://jurnal.fkip.uns.ac.id/index.php/s2math/article/view/9218

Warso, R. D. (2017). Pengembangan e-learning menggunakan schoology pada mata pelajaran mesin konversi energi di SMK Negeri 2 Tanjungbalai. Retrieved from http://digilib.unimed.ac.id/23677/

Widakdo, W. A. (2017). Mathematical Representation Ability by Using Project Based Learning on the Topic of Statistics. Journal of Physics: Conference Series, 895(1), 12055. IOP Publishing. 